membrane is surrounded on both sides by liquid. Pressure exercised on one part of this liquid mass does not force the retina against the wall-the fluid at the back preventing any such pressure being effective. A part may perhaps be forced out through the lymph paths, but owing to the great increase in the percentage of albumen in a part of the retina, there will undoubtedly be osmotic action in which the retina acts as a semipermeable membrane.

This explains why fluid enters in front of the retina and is discharged at the back.

I consider the effect of colmatage is partly due to this, and that $\frac{0}{0}$ it plays an important rôle in these cases in which the retina adheres after colmatage.

\title{
REFERENCES
}

Dieter.-Arch.f. Augenheilk., Vol. XCVI, 1925.

van Heuven.-Klin. Monatsbl. f. Augenheilk., Vol. LXXVI, 1926.

Lagrange.-Glaucome et Hypotonie. Paris : Doin, 1922.

Wesseley.-Arch. f. Ophthal., Vol. L, 1900; Heidelberg Congress, 1920 ; Arch.f. Augenheilk., Vols. LX, LXXVIII, LXXXIII, and LXXXVIII.

\section{THE HISTORY OF OPHTHALMOLOGY IN EGYPT}

BY

\author{
A. F. MacCallan, C.B.E.
}

LONDON

AN important communication on the history of ophthalmology in Egypt was made by Dr. Meyerhof at the Annual Congress of the Ophthalmological Society of Egypt in this year. It deals mainly with the Nineteenth Century, but his preface contains some items of great interest concerning earlier times. The excavation work of Dr. Reisner near the Pyramids of Giza is well known to Egyptologists, and his recent discovery should be known to ophthalmologists. He has found the funeral stele belonging to the earliest known oculist of human history, whose name is PEPI-ANKH or IRI. He practised both as an oculist and a magician at the court of one of the kings of the Sixth Dynasty, about 2500 B.C. This interesting document will shortly be published by Professor Junker of Vienna in the Aegyptische Zeitschrift.

The development of ophthalmology as shown in early Arabic literature has been studied also by Meyerhof, and an article on the subject appeared in the February number of this journal.

The first famous medical traveller in Egypt was the Venetian, $\stackrel{0}{\mathbb{D}}$ Prospero Alpino, who sojourned in Cairo from 1580 to 1584 . He published in Venice a book which saw many editions, the last 
being that of 1829. Prosper Alpinus, as he is usually called, gave the first exact records of the prevalence of ophthalmia in Egypt and of its increase during the hot season.

In 1598, Baron Harant of Poljitz, a Bohemian gentleman, visited Cairo and wrote a most original and intelligent description of his journey, a German translation of which appeared at Nuremberg in 1678. He was the first to describe the masses of flies on the eyes of the children, and to express the opinion that the flies were the cause of the ophthalmia, "as they soil, eat and infect them." The travels in Egypt of Tourtechot de Granger were described in a book published in Paris in 1745, wherein Egypt for the first time is called the "Land of the Blind."

That fascinating book "Travels to Discover the Source of the Nile," by James Bruce contains some details of interest to ophthalmologists. The seven volumes of the edition published in Edinburgh in 1813, containing the book-plate of Sir Auckland Colvin, were presented to the present writer as a token of friendship $b y$ Meyerhof, some years ago, or he would no doubt have given extracts. Bruce was a Scottish gentleman, who came to London when a young man, and married the daughter of a prosperous wine merchant ; after her death he travelled much on the Continent, and, with a view to voyages of discovery in Abyssinia, became British Consul at Algiers. In 1769, he went up the Nile to Kus in Upper Egypt; from thence across the desert to Kosseir on the Red Sea. From thence he proceeded by sea to Massowah, and penetrated to the interior of Abyssinia where he lived for several years, refusing important administrative positions, but placed in military commands occasionally during fighting. He returned via the Soudan, reaching Cairo in 1773. During a visit to Assouan, the Syene of Pliny, on his outward journey, he writes "though Syene by its situation should be healthy, the general complaint is a weakness and soreness in the eyes; you scarcely ever see a person in the street that sees with both." This observation was made in January, during the cool season when the average mid-day. temperature is 23.7 degrees $\mathrm{C}$.; the various micro-organisms which cause acute conjunctivitis have then full activity. Had Bruce's visit been made in June, July, or August he would have seen the same number of blind people perhaps, but very few with acute ophthalmia, as with a mid-day temperature of over 41 degrees, the micro-organisms causative of the inflammation become dormant, or at any rate their activity is restrained.

\section{The Nineteenth Century}

It is a well-known fact that Egyptian or Military Ophthalmia, as it was then called, attacked nearly all the European armies during the Napoleonic wars. It was a mixture of trachoma, 
blennorrhoea, and more harmless forms of conjunctivitis, probably mostly due to infections by the Koch-Weeks bacillus. It lasted until about 1850, and its history has been told again and again by physicians and surgeons. The Italian and German oculists shared the British opinion as to its contagious character, which was constantly denied by the French, and by several of the Belgian and Russian observers.

The Napoleonic campaign in Egypt has an important ophthalmic literature, much of which is referred to by Boldt (translation by Parsons and Snowball, London, 1904). The chief authority, as is well known is Larrey, but Meyerhof with the enthusiasm of a real bibliophile gives a number of others. Some of these seem to be sufficiently interesting to enumerate here : McGrigor, "Medical Sketches of the Expedition to Egypt from India," London, 1804; George Power, "Attempt to Investigate the Cause of the Egyptian Ophthalmia," London, 1803; Brigges in Trotter's "Medicina Nautica," London, 1804 ; Arthur Edmondston, "A Treatise on the Varieties and Consequences of Ophthalmia, with a Preliminary Inquiry into its Contagious Nature," Edinburgh and London, 1806 ; Douglas Whyte, "Mode of Managing Ocular Inflamma tion," Med. and Phys. Journal, 1802; Wittmann, "Travels ino Turkey and Across the Desert into Egypt," London, 1803; Louicis Frank, "De l'Ophtalmie d'Egypte," Paris, 1812; Deruez, "Essa sur 1'Ophtalmie d'Egypte," Strasburg, 1804; Desgenettes, "Histoire medicale de l'Armée de l'Orient," Paris, 1802; Bruant, "Notice sur 1'Ophtalmie regnante," Paris, 1800; Savaresi, "Descrizione dell'Oftalmia d'Egitto," Cairo, 1800.

\section{From 1800 to 1825}

The French scholars who accompanied the Emperor Napoleon to Egypt found no trace of scientific medicine remaining : the old Arabic traditions were lost. The only hospital in Cairo, and probably in the whole of Egypt, was that founded at the end of the Thirteenth Century by the Mameluke Sultan Qalawun. It had degenerated to a dirty prison by 1800 , where a few insane patients were kept in chains and treated with the whip. Immediately after the evacuation of Egypt by the French, their important sanitary institutions were destroyed or disorganized, in particular their ophthalmic hospital at Giza.

In 1805, Mohammed Ali, an Albanian adventurer, was nominated Pasha of Egypt, from whom the present sovereign is descended. Very soon the extraordinary gifts of this energetic and broadminded ruler became evident. He began to create avenues, squares, and sanitary establishments. He set a brilliant example of progressiveness by submitting one of his daughters to Jenner's 
new method of preventing small-pox, therebv attacking one of the principal causes of blindness.

\section{From 1826 to 1850}

When Mohammed Ali Pasha had firmly established his rule the urgent needs of his army compelled him to organize a sanitary service. In 1825, he nominated Antoine Clot,' a young French physician, as chief surgeon of the Egyptian Army, who will for ever be known as the illustrious Clot Bey. Clot Bey constructed a large military hospital and medical school at the depot of the army where 25,000 men were gathered together. The lectures of the European teachers had to be translated to the classes by interpreters. Then two learned brothers named el-Rashidi were sent to France for medical and linguistic education, who on their return translated and printed in Arabic some of the more important textbooks, including Sichel's textbook on ophthalmology. The difficulties arising from religious prejudice a hundred years ago may be imagined, and once Clot Bey's life was attempted in the anatomical theatre while performing an autopsy. Moreover envy and animosity among Europeans, and intrigues at the Pasha's court created many obstacles to Clot Bey's scheme of organization. In 1837, the military hospital was transferred to new buildings at Qasr-el-Ainy in Cairo, where there was accommodation for 1,500 sick soldiers and 300 medical students. Clot Bey and his assistant and successor Pruner, a capable German, left short writings on eye diseases in Egypt and on their treatment. Each rejected the theory of contagion in the case of both ophthalmia and plague. Clot Bey during his twenty-five years sojourn in Egypt suffered seventeen attacks of ophthalmia, to which he attributes the loss of vision in one eye, though this was more probably the result of detachment of the retina. During the wars of Mohammed Ali Pasha, Clot Bey saw thousands of Greek prisoners suffering from ophthalmia immediately after their transport to Egypt : the same was the case among the Syrian recruits sent to Egypt after 1832 ; in 1836, more than 20,000 of them were treated for ophthalmia with good results. To Clot Bey belongs the great credit of introducing nitrate of silver and sulphate of zinc into the therapy, of acute eye diseases.

\section{From 1850 to 1880}

After the death of Mohammed Ali Pasha and the short reign of his step-son Ibrahim Pasha, there followed under Abbas Pasha (1848-54) a certain reaction against French influence, during which Clot Bey was temporarily replaced by his German assistant Pruner Bey. The latter sent several medical student missions to Europe, 
one of which visited Gratz in Styria. Here the oculist Pieringer was working, who succeeded, aided perhaps by information obtained from the Egyptian students, in proving the identity of urethral and ocular gonorrhoea, and in separating clinically the blennorrhoea of the human eye from the other forms of acute conjunctivitis (Pieringer, "Die Blennorrhoe am Menschenauge," Gratz, 1841). . The distinguished Greek ophthalmologist Anagnostakis visited Egypt in 1851 and found the teaching of ophthalmology at Qasr-el-Ainy in the hands of a young native oculist who had received part of his medical education in Paris. However he had little success as the preliminary education of the medical students had been unsatisfactory, all the primary and secondary schools founded by Mohammed Ali Pasha having ceased to exist (Anagnostakis, "De l'Ophtalmologie en Grece et en Egypte," Compte-rendu du Congrès d'Ophtalmologie de Bruxelles, 1857; Paris, 1858). Anagnostakis should be remembered in trachomatous countries for having devised a satisfactory operation to correct entropion, at a time when either useless or devastating operations were in vogue. In 1856, in the reign of Said Pasha the Qasr-el-Ainy hospital and school of medicine were reorganized by the minister Edhem, competent European teachers beins obtained. About this time there was a certain amount of ophthal mic treatment carried out by general surgeons, but the study of? ophthalmology was neglected.

A new era began in 1869, when Dr. Tachau, a pupil of Albrecht von Graefe settled in Cairo and later in Alexandria. He was the first to introduce the modern operations for cataract and glaucoma, also plastic operations on the eyelids to relieve the sequelae of trachoma. After Tachau, Dr. Brugsch Bey settled in Cairo and had an enormous practice from 1878 until his death in 1894, after he had been nearly blinded by membranous conjunctivitis.

\section{From 1880 to 1900}

Egypt may be proud of the fact that the bacteriological era was partly inaugurated on her soil. Robert Koch in 1883 came to Alexandria to study the epidemic of cholera then raging. Besides discovering the comma bacillus, he examined the discharge from the eyes of persons suffering from ophthalmia in the summer, finding the gonococcus (discovered by Neisser in the urethral discharge in 1879), and in the slighter cases the thin rod-shaped bacillus (rediscovered five years later by John Weeks in New York), known as the Koch-Weeks bacillus. Kartulis, a distinguished Greek surgeon interested in bacteriology working at Alexandria, thought the Koch-Weeks bacillus was the cause of trachoma. 
Decisive progress in the bacteriological investigation of ocular infections in Egypt was made when Morax of Paris, in 1901, working at Alexandria, showed us how to distinguish the acute affections of the conjunctiva one from another, and from the chronic disease trachoma. He discovered the bacillus which is known as the Morax-Axenfeld bacillus (Morax, "Recherches cliniques et bactériologiques sur la conjunctivite granuleuse," Paris, 1902. Separate reprint from the Annales d'Oculistique). The work of Morax was continued by Lakah and Khouri (Annales d'Oculistique, 1902).

In 1889, Julius Hirschberg made a winter stay in Egypt and later published at Leipzig in 1890 an exhaustive historical and clinical study of trachoma. Ernst Fuchs visited Egypt at the end of the nineteenth century, as he has done many times since, and published sketches of what he had seen on the Nile.

There have been several Egyptian oculists of distinction, whose names are household words in Egypt, though long since dead. Eloui Pasha the chief of these received his medical education in France, and became Professor of Ophthalmology at the Government Medical School in Cairo. He read an interesting paper on trachoma at the International Congress of Medicine held in Cairo in 1902. It is interesting to remember that he ceased to be a member of the Ophthalmological Society of Egypt in 1911, as objection was raised by members to widespread advertisements issued by a drug store in which he had a financial interest, of "Dr. Eloui Pasha's Eye Drops." Other specialists were Saad Bey Sameh, Owf Pasha, and Ali Bey Haidar. Among the many foreigners practising in Egypt first must be noted Max Meyerhof to whose erudition the material of this article is due; Alfred Osborne, a pupil of the Archduke Karl Theodor, whose suggestion of utilizing the Cassel ophthalmic benefaction for the provision of travelling ophthalmic hospitals, was accepted; Peretz, a pupil of Truc of Montpellier; Demetriades and Jacovides, both of whom still practise at Alexandria.

Shortly after the British occupation of Egypt in 1882 Kenneth Scott, and later Fischer, occupied the post of chief ophthalmic surgeon at Qasr-el-Ainy; under them a very adequate teaching organization was developed. One of their assistants was a very dexterous Egyptian surgeon, Bayoumi Bey, from whom the present writer obtained much practical help.

\section{From 1900 to the present day}

Dr. Alfred Osborne of Alexandria, who has been mentioned above, at the same Annual Congress of the Ophthalmological Society of Egypt, made a communication on the ophthalmic history of Egypt from 1900 to the present day. The important 
clinical, pathological, and historical work carried on for many years by Osborne, Meyerhof, and Peretz should always be $\overrightarrow{0}$ remembered, when stress is laid on the more spectacular work carried out by the present ophthalmic organization of the Egyptian Government. This originated in the financial provision of two travelling ophthalmic hospitals by Sir Ernest Cassel. Their \& success under careful professional and political management has $\vec{o}$ allowed the development of the numerous specially designed and built ophthalmic hospitals in the larger towns, while travelling hospitals tour the more remote districts. There is a special teaching hospital in the environs of Cairo, and adjoining it a special ophthalmic laboratory, which is a separate and monumental building, and is probably the best ophthalmic laboratory in the world. At the present time a British ophthalmologist and a British pathologist receive from British sources adequate remuneration for teaching and research work, and it is expected that their labours will throw further light on the causative factor of trachoma. The staff of the Ophthalmic Hospitals (which form a section of the Department of Public Health) consists of Egyptian surgeons, two for each hospital, who received their post-graduate ophthalmic training from the former Britisl $\$ \overrightarrow{0}$ Director of the Egyptian Ophthalmic Hospitals, between 190. and 1924. The annual cost of the Ophthalmic Department to the Egyptian Government is now about $£ 60,000$ a year. A prosperous and scientific school of ophthalmologists has therefore arisen in Egypt so long called the "Land of the Blind." The Ophthalmological Society now has 100 members, and publishes an annual bulletin containing an account of its activities, copies of which may be obtained from the honorary secretary of the Society (c/o the Department of Public Health, Cairo). The reports of the British Director of Ophthalmic Hospitals have been printed and published from 1912 to 1922 by the Government Printing Press, Cairo, containing accounts of clinical and pathological research.

Since arrangements for ophthalmic treatment have been provided in most of the large towns and even in the remote country districts, it will naturally be asked if there has resulted any appreciable diminution of blindness. This may be answered by Professor Fuchs, certainly one of the best ophthalmic observers now living, who wrote in 1924: "The result of these campaigns against diseases of the eye is best noted by the decrease in the number of blind persons. When I visited Egypt for the first time some 30 years ago it was a common sight in the larger towns to see four or more blind persons being led about through the streets by .a half-blind man."

The Fourth International Congress for the Amelioration of the lot of the Blind was held in Cairo in 1911, when proposals were 
made for the establishment of a vast educational establishment for the blind (vide the Ophthalmoscope for December, 1911). Such a scheme would have diverted Government funds from the then barely established organization for the treatment of eye diseases and required some trouble to defeat. The lot of the blind in Egypt is not so hard as in other countries, and as Dr. Osborne points out it is difficult to get inmates for the existing blind schools at Cairo and Alexandria.

A systematic and regular ophthalmic inspection of the schools is now carried out by the ophthalmic staff of the Department of Public Health, which is combined with an efficient organiżation for treatment of those with active trachoma or other. forms of conjunctivitis, in the schools themselves.

Dr. Osborne concludes his paper by saying: "Egypt may well be proud of what has been achieved."

\title{
SOME NOTES ON SARCOMA OF THE UVEAL TRACT
}

\author{
BY \\ R. C. DAVENPORT \\ MOORFIELDS RESEARCH SCHOLAR \\ LONDON
}

IN Vol. XIII, p. 104, of the Ophthalmic Hospital Reports, Lawford and Collins published a paper giving details of a series of 103 cases of sarcoma of the uveal tract treated at Moorfields from 1871-1890. Marshall followed this in Vol. XV, p. 51, with a series of 58 similar cases from 1891-1898. The present paper records a similar series of 35 cases, at Moorfields in 5 years, October, 1918-October, 1923.

Frequency.-The first point of interest is the consistent yearly incidence at Moorfields. Over the whole period, 1871-1925, 55 years, there are recorded 345 cases where an excised eye was found to contain a sarcoma of the uveal tract. This gives an average of just over 6 per year. In the 28 years previously recorded there were 161 cases, viz., just under 6 per year, and in my collected cases the average is exactly 7 .

In the other series a few extraneous cases were published so that the actual Moorfields figure then was slightly under 6 per year. The regularity of incidence over so many years is somewhat striking, however, although the increase is less sharp than might be expected in recent years when the figures for new patients are almost double those for 1870-1890. One factor possibly bearing on this was the difficulty in pathological work and reports in the years 